\title{
Synthesis and structures of polymeric silver and mercury complexes with amido-functionalized $\mathrm{N}$-heterocyclic carbenes
}

\author{
Shou-Chon Chen ${ }^{a}$, Hsin-Hsueh Hsueh ${ }^{a}$, Chun-Hung Chen ${ }^{a}$, Chen Shiang Lee ${ }^{a}$, Fu-Chen Liu ${ }^{a}$,* \\ Ivan J.B. Lin ${ }^{\mathrm{a}, *}$, Gene-Hsian Lee ${ }^{\mathrm{b}}$, Shie-Ming Peng ${ }^{\mathrm{b}}$ \\ ${ }^{a}$ Department of Chemistry, National Dong Hwa University, 1, Sec. 2, Da Hsueh Rd., Shou-Feng, Hualien 974, Taiwan, ROC \\ ${ }^{\mathrm{b}}$ Department of Chemistry, National Taiwan University, Taipei 106, Taiwan, ROC
}

\section{A R T I C L E I N F O}

\section{Article history:}

Received 25 November 2008

Received in revised form 5 March 2009

Accepted 9 March 2009

Available online 18 March 2009

\section{Keywords:}

Silver carbene

Mercury carbene

Acetamide

Hydrogen bond

Amide

Amido

\begin{abstract}
A B S T R A C T
Four amido-functionalized $\mathrm{N}$-heterocyclic silver(I) and mercury(II) carbene complexes, [ $\left(\mathrm{CH}_{3}\right.$-imy$\left.\left.\mathrm{CH}_{2} \mathrm{CONH}_{2}\right)_{2} \mathrm{Ag}_{2} \mathrm{Br}_{2}\right]$ (3), $\left[\mathrm{Ag}\left(\mathrm{CH}_{3} \text {-bimy- } \mathrm{CH}_{2} \mathrm{CONH}_{2}\right)_{2}\right]_{4}\left[\mathrm{Ag}_{4} \mathrm{Br}_{8}\right]$ (4), [ $\left.\mathrm{Hg}\left(\mathrm{CH}_{3} \text {-imy- } \mathrm{CH}_{2} \mathrm{CONH}_{2}\right)_{2}\right]\left[\mathrm{HgBr}_{4}\right]$ (5), and $\left[\mathrm{Hg}\left(\mathrm{CH}_{3} \text {-bimy- } \mathrm{CH}_{2} \mathrm{CONH}_{2}\right)_{2}\right]\left[\mathrm{HgBr}_{4}\right](\mathbf{6})$, have been synthesized and structurally characterized. Crystal packing revealed a 2D polymeric structure of complex $\mathbf{3}$. In addition to a repeated interaction between the $\mathrm{Ag}_{2} \mathrm{Br}_{2}$ units responsible for the $1 \mathrm{D}$ polymeric ladder structure, a pair of hydrogen bonding interactions between the amido groups of the adjacent molecules provided a basis for the other dimension of the polymeric chain. Complex 4 is comprised of a unique oligomeric anion $\left[\mathrm{Ag}_{4} \mathrm{Br}_{8}\right]^{4-}$ and four $\left[\mathrm{Ag}\left(\mathrm{CH}_{3} \text {-bimy- } \mathrm{CH}_{2} \mathrm{CONH}_{2}\right)_{2}\right]^{+}$cations. Crystal packing of 4 revealed a one-dimensional polymeric structure in which the cations are connected to each other through a pair of hydrogen bonding interactions between the adjacent amido groups. Compounds $\mathbf{5}$ and $\mathbf{6}$ are both ionic consisting of a mercury carbene cation and $\left[\mathrm{HgBr}_{4}\right]^{2-}$ anion. An intramolecular interaction of the amido oxygen with the mercury atom of the cation was observed in these two complexes. The interaction between the mercury of the cation and a bromide of the anion, along with the hydrogen bonding interaction of the adjacent amido groups, is responsible for the $2 \mathrm{D}$ polymeric structures of these two complexes in the solid state.
\end{abstract}

(c) 2009 Elsevier B.V. All rights reserved.

\section{Introduction}

Since N-heterocyclic carbene (NHCs) complexes had been independently prepared by Öfele [1] and Wanzlick and Schönherr [2-4] and the first synthesis of a stable N-heterocyclic carbene by Arduengo et al. in 1991 [5], the chemistry of imidazole-2-ylidene (imy) and benzimidazole-2-ylidene (bimy) have received considerable attention. NHC carbene, a strong $\sigma$-donor and a weak $\pi$-acceptor, strongly interacts with different transitions metals in various oxidation states [6-9]. This electronic property combined with the steric effect of the substituents on the nitrogen atoms next to the carbene carbon atom provide a basis for the increased catalytic activity and selectivity of these carbene complexes [10-13]. Thus, extensive catalytic studies in the field of application to organic synthesis have been reported [14-19]. Furthermore, the diversity of their structures resulting from, for example, extended metal-metal interactions, metal-bridging halides and carbenes, intermolecular hydrogen bonds and $\pi-\pi$ interactions, may lead to interesting structural motifs, such as supramolecular architectures, as well as to inorganic-organic hybrid materials [20-25]. Our interest has been the influence of a carbene functionalized sidearm on

\footnotetext{
* Corresponding authors. Tel.: +886 3 8633601; fax: +886 38633570 (F.-C. Liu)

E-mail address: fcliu@mail.ndhu.edu.tw (F.-C. Liu).
}

the structural diversity of the related metal carbene complexes. We have reported the acetamide functionalized carbene complexes [ $\left.\mathrm{Hg}\left(2 \text {-pyrazinyl-imy- } \mathrm{CH}_{2} \mathrm{CONH}_{2}\right)_{2}\right] \mathrm{X} \quad\left(\mathrm{X}=\mathrm{PF}_{6}, \mathrm{BF}_{4}\right)$ and $[\mathrm{Hg}(2-$ pyrimidyl-imy- $\left.\left.\mathrm{CH}_{2} \mathrm{CONH}_{2}\right)_{2}\right] \mathrm{X}\left(\mathrm{X}=\mathrm{BF}_{4}\right)$ [26], in which the amido groups are located on the same side. Intermolecular hydrogen bonding interaction between the amido groups of the adjacent molecules leads to a rectangular architecture. Recently, several structurally diverse acetamide functionalized carbene complexes have been also published by Ghosh and co-workers $[27,28]$. Here the results of our recent studies of the silver and mercury complexes with amido-functionalized N-heterocyclic carbene are reported. Due to the intermolecular hydrogen bonding interactions and the interaction between the packing units, 1D and 2D supramolecular architectures have been obtained.

\section{Experimental}

\subsection{General procedures}

All solvents and chemicals were of the analytical reagent grade and used as received from the commercial suppliers. Elemental analysis was carried out on a Perkin-Elmer CHN-2400 microanalyzer. Proton spectra $(\delta(\mathrm{TMS})=0.00 \mathrm{ppm})$ were recorded either on a Bruker Avance DPX300 or a Bruker Avance II 400 spectrometer 
Table 1

Crystallographic data for 1-methylacetamido-3-methylbenzimidazolium bromide (1) and 1-methylacetamido-3-methylbenzimidazolium bromide (2).

\begin{tabular}{|c|c|c|}
\hline Empirical formula & $\mathrm{C}_{6} \mathrm{H}_{10} \mathrm{BrN}_{3} \mathrm{O}$ & $\mathrm{C}_{10} \mathrm{H}_{12} \mathrm{BrN}_{3} \mathrm{O}$ \\
\hline Formula weight & 220.08 & 270.14 \\
\hline$T(\mathrm{~K})$ & $150(1)$ & $298(2)$ \\
\hline Crystal system & monoclinic & monoclinic \\
\hline Space group & $P 2(1) / c$ & $P 2(1) / c$ \\
\hline$a(\AA)$ & $9.2125(8)$ & $11.7618(10)$ \\
\hline$b(\AA)$ & $12.3382(10)$ & $10.8773(9)$ \\
\hline$c(\AA)$ & $8.3641(7)$ & $9.2222(8)$ \\
\hline \multicolumn{3}{|l|}{$\alpha\left({ }^{\circ}\right)$} \\
\hline$\beta\left(^{\circ}\right)$ & $113.215(2)$ & $108.489(2)$ \\
\hline \multicolumn{3}{|l|}{$\gamma\left({ }^{\circ}\right)$} \\
\hline$V\left(\AA^{3}\right)$ & 873.73(13) & $1118.96(16)$ \\
\hline$Z$ & 4 & 4 \\
\hline$\rho_{\text {calc }}\left(\mathrm{g} / \mathrm{cm}^{3}\right)$ & 1.673 & 1.604 \\
\hline Crystal size $\left(\mathrm{mm}^{3}\right)$ & $0.25 \times 0.20 \times 0.20$ & $0.35 \times 0.35 \times 0.25$ \\
\hline Radiation $(\lambda, \AA)$ & Мo K $\alpha(0.71073)$ & Mo K $\alpha(0.71073)$ \\
\hline$\theta$ limits $\left(^{\circ}\right)$ & $2.41-27.50$ & $1.83-27.49$ \\
\hline \multirow[t]{3}{*}{ Index ranges } & $-8 \leqslant h \leqslant 11$ & $-14 \leqslant h \leqslant 15$ \\
\hline & $-15 \leqslant k \leqslant 16$ & $-14 \leqslant k \leqslant 14$ \\
\hline & $-10 \leqslant l \leqslant 10$ & $-11 \leqslant l \leqslant 11$ \\
\hline Reflections collected & 5508 & 10619 \\
\hline Unique reflections & 1992 & 2563 \\
\hline$F(000)$ & 440 & 544 \\
\hline Completeness to $\Theta(\%)$ & 99.9 & 99.9 \\
\hline$\mu\left(\mathrm{mm}^{-1}\right)$ & 4.654 & 3.651 \\
\hline Data/restraints/parameters & $1992 / 0 / 101$ & $2563 / 0 / 137$ \\
\hline$R_{1}^{\mathrm{a}}[I>2.0 \sigma(I)]$ & 0.0309 & 0.0333 \\
\hline$w R_{2}^{\mathrm{b}}$ (all data) & 0.0773 & 0.0831 \\
\hline$R_{\text {int }}$ & 0.0289 & 0.0325 \\
\hline Goodness-of-fit on $F^{2}$ & 1.011 & 1.011 \\
\hline
\end{tabular}

a $R_{1}=\sum\left\|\mathrm{F}_{\mathrm{o}}\right\|-\left|\mathrm{F}_{\mathrm{c}}\left\|/ \sum\right\| \mathrm{F}_{\mathrm{o}}\right|$.

b $w R_{2}=\left\{\sum w\left(F_{\mathrm{o}}^{2}-F_{\mathrm{c}}^{2}\right)^{2} / \sum w\left(F_{\mathrm{o}}^{2}\right)^{2}\right\}^{1 / 2}$.

operating at $300.130 \mathrm{MHz}$ and $400.132 \mathrm{MHz}$, respectively. Infrared spectra were recorded on a Jasco FT/IR-460 Plus spectrometer with $2 \mathrm{~cm}^{-1}$ resolution.

\subsection{X-ray structure determination}

Crystallographic data collections were carried out on a Nonius KappaCCD diffractometer with graphite-monochromated Mo K $\alpha$ radiation $(\lambda=0.71073 \AA$ ) at $150(2)$ or $298(2) \mathrm{K}$. Unit cell parameters were retrieved and refined using DENZO-SMN [29] software on all reflections. Data reduction was performed with the DENZO-SMN [29] software. An empirical absorption was based on the symmetry-equivalent reflections and was applied to the data using SORTAV $[30,31]$ program. The structure was solved using the sHELXs-97 [32] program and refined using SHELXL-97 [33] program by full-matrix least-squares on $F^{2}$ values. All nonhydrogen atoms were refined anisotropically. The hydrogen atoms were fixed at calculated positions and refined using a riding mode. Crystallographic data of 3-6 are summarized in Table 1.

\subsection{Preparation of complexes}

\subsubsection{1-Methylacetamido-3-methylimidazolium bromide (1)}

1-Methylimidazole $(84.2 \mathrm{mg}, 1.0 \mathrm{mmol}), 2$-bromoacetamide (139.8 $\mathrm{mg}, 1.0 \mathrm{mmol}$ ) and about $15 \mathrm{~mL}$ of acetonitrile were placed into a $50 \mathrm{~mL}$ flask. The flask was heated to reflux under nitrogen causing a formation of a white precipitate. After refluxing for $8 \mathrm{~h}$, the solvent was removed, and the solid was washed with $20 \mathrm{~mL}$ of $\mathrm{CH}_{2} \mathrm{Cl}_{2}$. The resulting white solid was dissolved in methanol and kept at $0{ }^{\circ} \mathrm{C}$ for crystallization. Colorless crystals were obtained (94.3 mg, 42\% yield). Anal. Calc. for $\mathrm{C}_{6} \mathrm{H}_{10} \mathrm{BrN}_{3} \mathrm{O}: \mathrm{C}, 32.75 ; \mathrm{H}, 4.58$; $\mathrm{N}, 19.09$. Found: C, 32.63; H, 4.52; N, 19.01\%. ${ }^{1} \mathrm{H}$ NMR (DMSO- $d_{6}$ ): $\delta$ $9.08(\mathrm{~s}, 1 \mathrm{H}, \mathrm{NCHN}), 7.86\left(\mathrm{~s}, 1 \mathrm{H}, \mathrm{NH}_{2}\right), 7.68(\mathrm{~s}, 2 \mathrm{H}, \mathrm{CH}=\mathrm{CH}), 7.51(\mathrm{~s}$, $\left.1 \mathrm{H}, \mathrm{NH}_{2}\right), 4.96\left(\mathrm{~s}, 2 \mathrm{H}, \mathrm{CH}_{2}\right)$, and $3.88 \mathrm{ppm}\left(\mathrm{s}, 3 \mathrm{H}, \mathrm{CH}_{3}\right) .{ }^{13} \mathrm{C} \mathrm{NMR}$ $\left(\right.$ DMSO- $\left.d_{6}\right): \delta 167.22(\mathrm{CO}), 138.14(\mathrm{NCN}), 124.21 \quad(\mathrm{CH}=\mathrm{CH})$, $123.38(\mathrm{CH}=\mathrm{CH}), 50.92\left(\mathrm{CH}_{2}\right)$, and $36.30 \mathrm{ppm}\left(\mathrm{CH}_{3}\right)$. IR $(\mathrm{KBr})$ : 3373(vw), 3288(m), 3168(s), 2993(vw), 2928(vw), 2851(vw), 2797(vw), 2732(vw), 1687(vs), 1626(w), 1572(w), 1560(w), 1438 (vw), 1396(vw), 1342(m), 1304(m), 1263(vw), 1174(m), 1125 (vw), 1091(vw), 1036(w), 1018(vw), 972(vw), 864(vw), 843(vw), 787(vw), 756(vw), 675(w), 651(w), 623(m), 598(w), and 551(vw) $\mathrm{cm}^{-1}$.

\subsubsection{1-Methylacetamido-3-methylbenzimidazolium bromide (2)}

The preparation of $\left[\mathrm{CH}_{3}-\mathrm{Bim}-\mathrm{CH}_{2} \mathrm{CONH}_{2}\right] \mathrm{Br}$ was similar to that of compound 1. From $132.1 \mathrm{mg}$ of 1 -methylbenzimidazole (1.0 $\mathrm{mmol}$ ) and $139.6 \mathrm{mg}$ of 2-bromoacetamide $(1.0 \mathrm{mmol}), 189.0 \mathrm{mg}$ of colorless crystals were obtained (70.0\% yield). Anal. Calc. for $\mathrm{C}_{10} \mathrm{H}_{12} \mathrm{BrN}_{3} \mathrm{O}$ : C, 44.46; $\mathrm{H}, 4.48 ; \mathrm{N}, 15.56$. Found: $\mathrm{C}, 44.44 ; \mathrm{H}$, 4.49; N, 15.51\%. ${ }^{1} \mathrm{H}$ NMR (DMSO- $\left.d_{6}\right): \delta 9.79(\mathrm{~s}, 1 \mathrm{H}, \mathrm{NCHN}), 8.03$ $\left(\mathrm{m}, 2 \mathrm{H}, \mathrm{C}_{6} \mathrm{H}_{4}, \mathrm{NH}_{2}\right), 7.94\left(\mathrm{~m}, 1 \mathrm{H}, \mathrm{C}_{6} \mathrm{H}_{4}\right), 7.68\left(\mathrm{~m}, 3 \mathrm{H}, \mathrm{C}_{6} \mathrm{H}_{4}, \mathrm{NH}_{2}\right)$, $5.33\left(\mathrm{~s}, 2 \mathrm{H}, \mathrm{CH}_{2}\right)$, and $4.13 \mathrm{ppm}\left(\mathrm{s}, 3 \mathrm{H}, \mathrm{CH}_{3}\right) .{ }^{13} \mathrm{C}$ NMR (DMSO$\left.d_{6}\right): \delta 167.00(\mathrm{CO}), 144.15(\mathrm{NCN}), 131.97,131.92,127.16,126.92$, 114.11, $113.92\left(\mathrm{C}_{6} \mathrm{H}_{4}\right), 48.79\left(\mathrm{CH}_{2}\right)$, and $33.88 \mathrm{ppm}\left(\mathrm{CH}_{3}\right)$. IR (KBr): 3305(vw), 3236(vw), 3138(s), 3033(vw), 2979(vw), 2942 (vw), 1793(vw), 1691(vs), 1680(vs), 1612(w), 1568(m), 1487(vw), 1460(w), 1444(w), 1414(vw), 1387(m), 1367(vw), 1346(vw), 1292(m), 1279(w), 1215(w), 1203(w), 1165(vw), 1142(vw), 1128 (vw), 1111(vw), 1090(vw), 1030(vw), 1012(vw), 980(vw), 941 (vw), 902(vw), 845(vw), 804(vw), 767(m), 756(m), 652(vw), 617(vw), 595(vw), 569(w), 534(vw), 507(vw), and 426(w) $\mathrm{cm}^{-1}$.

\subsubsection{1-Methylacetamido-3-methylimidazol-2-ylidene silver bromide (3)}

1-Acetamido-3-methylimidazolium bromide $(0.4413 \mathrm{~g}, \quad 2.0$ mmol) and silver oxide ( $232.1 \mathrm{mg}, 1.0 \mathrm{mmol})$ were placed into a $50 \mathrm{~mL}$ flask. The flask was covered with aluminium foil followed by a transfer of about $20 \mathrm{~mL}$ of $\mathrm{CH}_{2} \mathrm{Cl}_{2}$ into the flask. After stirring for 1 day, the solution was removed by filtration and the resulting white solid was washed with $\mathrm{CH}_{2} \mathrm{Cl}_{2}$ several times. The resulting white solid was dissolved in DMSO for crystallization. Colorless crystals were obtained $(241.9 \mathrm{mg}, 37 \%$ yield). Anal. Calc. for $\mathrm{C}_{12} \mathrm{H}_{18} \mathrm{Ag}_{2} \mathrm{Br}_{2} \mathrm{~N}_{6} \mathrm{O}_{2}$ : C, 22.04; $\mathrm{H}, 2.77 ; \mathrm{N}, 12.85$. Found: C, 22.07; $\mathrm{H}, 2.90 ; \mathrm{N}, 12.78 \% .{ }^{1} \mathrm{H}$ NMR (DMSO-d 6 ): $\delta 7.63\left(\mathrm{~s}, 1 \mathrm{H}, \mathrm{NH}_{2}\right), 7.37$ $(\mathrm{s}, 2 \mathrm{H}, \mathrm{CH}=\mathrm{CH}), 7.31\left(\mathrm{~s}, 1 \mathrm{H}, \mathrm{NH}_{2}\right), 4.75\left(\mathrm{~s}, 2 \mathrm{H}, \mathrm{CH}_{2}\right)$, and $3.77 \mathrm{ppm}$ $\left(\mathrm{s}, 3 \mathrm{H}, \mathrm{CH}_{3}\right) .{ }^{13} \mathrm{C}$ NMR (DMSO-d 6 ): $\delta 181.65(\mathrm{NCN}), 169.06(\mathrm{CO})$, $123.87(\mathrm{CH}=\mathrm{CH}), 122.87(\mathrm{CH}=\mathrm{CH}), 53.21\left(\mathrm{CH}_{2}\right)$, and $38.54 \mathrm{ppm}$ $\left(\mathrm{CH}_{3}\right)$. IR (KBr, cm $\left.{ }^{-1}\right)$ : 3398(m), 3306(vw), 3237(vw), 3184(w), 3138(vw), 3107(vw), 2935(vw), 1683(s), 1621(w), 1568(vw), 1549(vw), 1471(vw), 1449(vw), 1430(vw), 1401(vw), 1391(w), 1357(vw), 1341(vw), 1308(w), 1230(w), 1193(vw), 1139(vw), 1100(vw), 1081(vw), 1032(vw), 962(vw), 875(vw), 824(vw), 801(vw), 760(vw), 717(w), 702(vw), 622(vw), 610(vw), 553(vw), and $496(\mathrm{w})$.

\subsection{4. [\{1-(Methylacetamido)-3-(methylbenzimidazol-2-ylidene $)\}_{2}$ $\mathrm{Ag}]_{4}\left[\mathrm{Ag}_{4} \mathrm{Br}_{8}\right]$ (4)}

The preparation was similar to that of 3 . From $541.2 \mathrm{mg}$ (2.0 mmol) of 1-acetamido-3-methylbenzimidazolium bromide and $230.5 \mathrm{mg}$ (1.0 mmol) of silver oxide, $750.4 \mathrm{mg}(98 \%)$ of $4 \cdot 2 \mathrm{H}_{2} \mathrm{O}$ was isolated after washing with $\mathrm{CH}_{2} \mathrm{Cl}_{2}$. A crystal suitable for X-ray diffraction analysis was isolated from DMSO solution. Anal. Calc. for $\mathrm{C}_{80} \mathrm{H}_{88} \mathrm{Ag}_{8} \mathrm{Br}_{8} \mathrm{~N}_{24} \mathrm{O}_{8} \cdot 2 \mathrm{H}_{2} \mathrm{O}: \mathrm{C}, 31.48 ; \mathrm{H}, 3.04 ; \mathrm{N}$, 11.01. Found: $\mathrm{C}, 31.33 ; \mathrm{H}, 3.07 ; \mathrm{N}, 11.07 \% .{ }^{1} \mathrm{H}$ NMR (DMSO- $\left.d_{6}\right): \delta$ $7.76\left(\mathrm{~m}, 2 \mathrm{H}, \mathrm{C}_{6} \mathrm{H}_{4}, \mathrm{NH}_{2}\right), 7.64\left(\mathrm{~m}, 1 \mathrm{H}, \mathrm{C}_{6} \mathrm{H}_{4}\right), 7.44\left(\mathrm{~m}, 3 \mathrm{H}, \mathrm{C}_{6} \mathrm{H}_{4}\right.$, $\left.\mathrm{NH}_{2}\right), 5.12\left(\mathrm{~s}, 2 \mathrm{H}, \mathrm{CH}_{2}\right)$, and $4.05 \mathrm{ppm}\left(\mathrm{s}, 3 \mathrm{H}, \mathrm{CH}_{3}\right) \cdot{ }^{13} \mathrm{C} \mathrm{NMR}$ (DMSO- $\left.d_{6}\right): \delta 192.31(\mathrm{NCN}), 168.69(\mathrm{CO}), 134.42,134.25,124.44$, 124.29, $112.38\left(\mathrm{C}_{6} \mathrm{H}_{4}\right), 50.99\left(\mathrm{CH}_{2}\right)$, and $36.00 \mathrm{ppm}\left(\mathrm{CH}_{3}\right)$. IR (KBr): 3332(m), 3318(m), 3161(m), 3034(vw), 2993(vw), 2977 (vw), 2935(w), 2918(w), 2912(w), 2831(vw), 2786(vw), 2360 
$(\mathrm{vw}), \quad 2338(\mathrm{vw}), \quad 1686(\mathrm{vs}), \quad 1641(\mathrm{vw}), \quad 1610(\mathrm{vw}), \quad 1480(\mathrm{vw})$, 1465(vw), 1438(s), 1392(s), 1346(vw), 1311(s), 1269(vw), 1204 (w), 1173(vw), 1131(vw), 1104(vw), 1033(vw), 1026(s), 978(vw), 951(vw), 932(vw), 867(vw), 821(vw), 792(vw), 764(s), 740(s), 710(vw), 618(m), 606(m), 580(m), 508(vw), and 434(w) $\mathrm{cm}^{-1}$.

\subsection{5. [\{1-(Methylacetamido)-3-(methylimidazol-2-ylidene $\left.)\}_{2} \mathrm{Hg}\right]$} $\left[\mathrm{HgBr}_{4}\right](\mathbf{5})$

1-Acetamido-3-methylimidzolium bromide $(110.7 \mathrm{mg}, \quad 0.5$ $\mathrm{mmol})$ and mercury acetate $(81.0 \mathrm{mg}, 0.25 \mathrm{mmol})$ were placed into a $50 \mathrm{~mL}$ flask followed by a transfer of about $20 \mathrm{~mL}$ of $\mathrm{CH}_{3} \mathrm{CN}$ into the flask. After refluxing for 1 day, the solution was removed by filtration, and the resulting white solid was washed with $\mathrm{CH}_{3} \mathrm{CN}$ several times. A white solid was obtained ( $99.3 \mathrm{mg}$, 39.8\% yield). Anal. Calc. for $\mathrm{C}_{12} \mathrm{H}_{18} \mathrm{Br}_{4} \mathrm{Hg}_{2} \mathrm{~N}_{6} \mathrm{O}_{2}$ : C, 14.43; $\mathrm{H}, 1.82 ; \mathrm{N}, 8.41$. Found: $\mathrm{C}$, 14.33.82; H, 1.90; N, 8.49\%. ${ }^{1} \mathrm{H}$ NMR (DMSO- $\left.d_{6}\right): \delta 7.84(\mathrm{~s}, 1 \mathrm{H}$, $\left.\mathrm{NH}_{2}\right), 7.64(\mathrm{~s}, 1 \mathrm{H}, \mathrm{CH}=\mathrm{CH}), 7.63(\mathrm{~s}, 1 \mathrm{H}, \mathrm{CH}=\mathrm{CH}), 7.46(\mathrm{~s}, 1 \mathrm{H}$, $\left.\mathrm{NH}_{2}\right), 5.17\left(\mathrm{~s}, 2 \mathrm{H}, \mathrm{CH}_{2}\right)$, and $3.98 \mathrm{ppm}\left(\mathrm{s}, 3 \mathrm{H}, \mathrm{CH}_{3}\right) .{ }^{13} \mathrm{C} \mathrm{NMR}$ $\left(\mathrm{DMSO}-\mathrm{d}_{6}\right): \delta 177.66(\mathrm{NCN}), 168.74(\mathrm{CO}), 124.96(\mathrm{CH}=\mathrm{CH})$, $124.36(\mathrm{CH}=\mathrm{CH}), 52.46\left(\mathrm{CH}_{2}\right)$, and $38.22 \mathrm{ppm}\left(\mathrm{CH}_{3}\right)$. IR $(\mathrm{KBr})$ : 3353(m), 3279(s), 3149(s), 3122(s), 2965(vw), 2924(vw), 2801(vw), 2755(vw), 2357(vw), 2287(vw), 2219(vw), 1943(vw),<smiles>Cn1ccnc1</smiles>

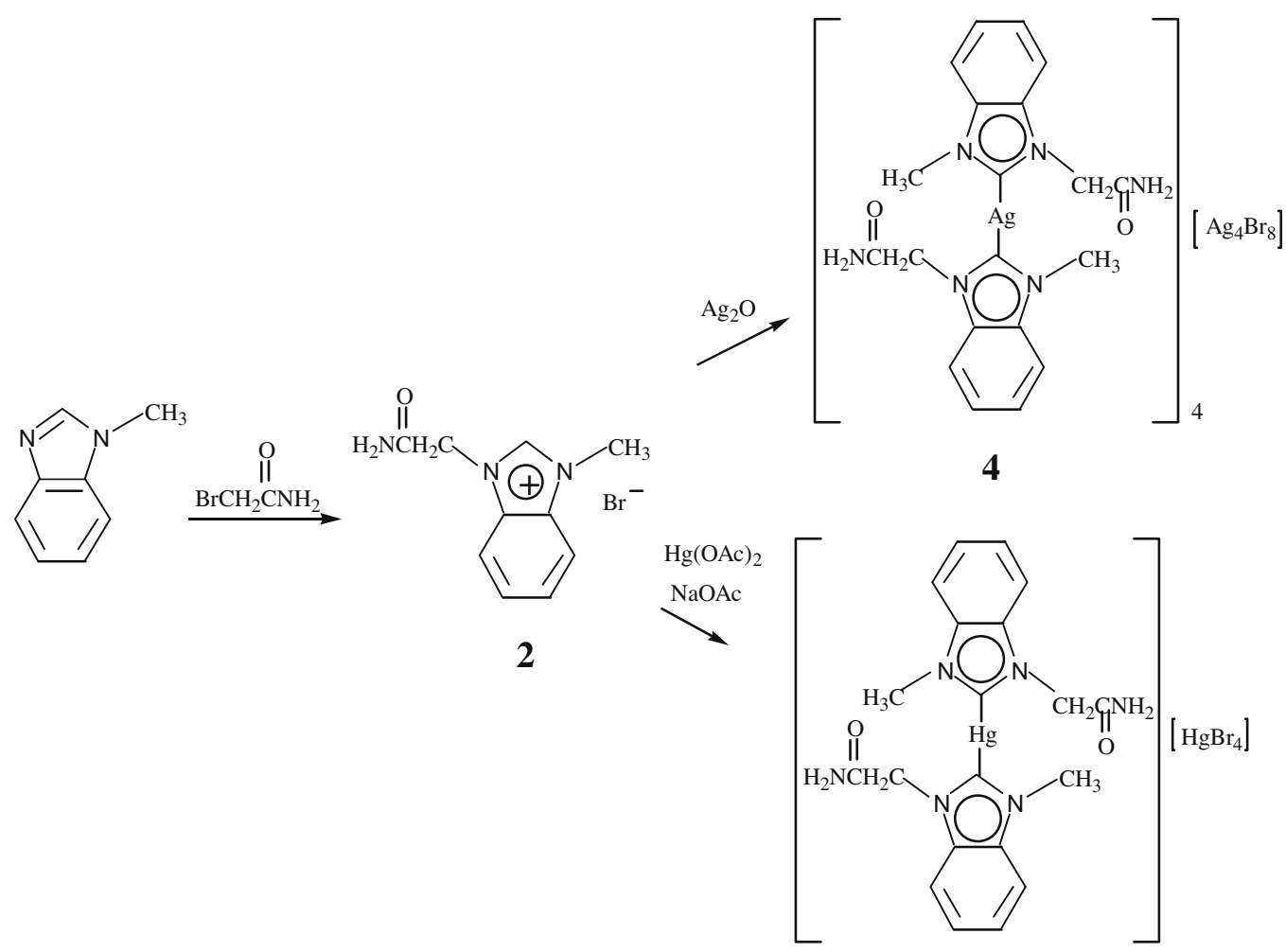




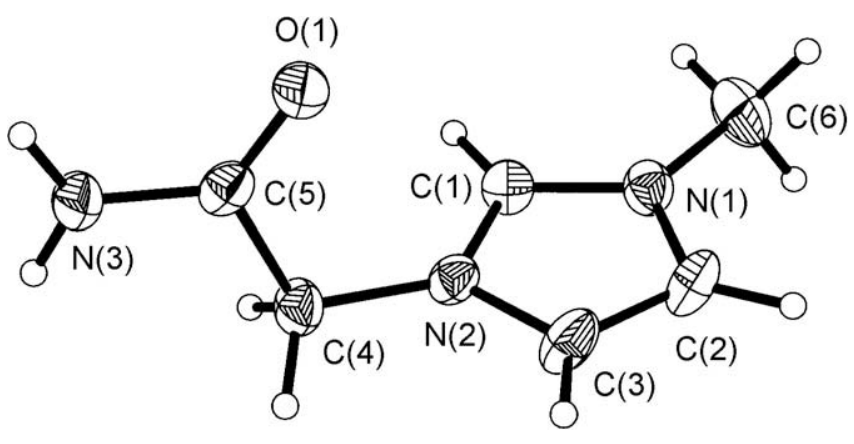

Fig. 1. Molecular structure of the cation in 1 showing $50 \%$ probability thermal ellipsoids. Selected bond lengths $(\AA)$ and angles $\left({ }^{\circ}\right)$ : $\mathrm{C}(1)-\mathrm{N}(1)$ : $1.322(3) ; \mathrm{C}(1)-\mathrm{N}(2)$ : 1.331(3); $\mathrm{C}(5)-\mathrm{O}(1): 1.222(3) ; \mathrm{C}(5)-\mathrm{N}(3): 1.326(3) ; \mathrm{C}(5)-\mathrm{N}(3): 1.326(3) ; \mathrm{N}(1)-$ $\mathrm{C}(1)-\mathrm{N}(2): 108.7(2)$

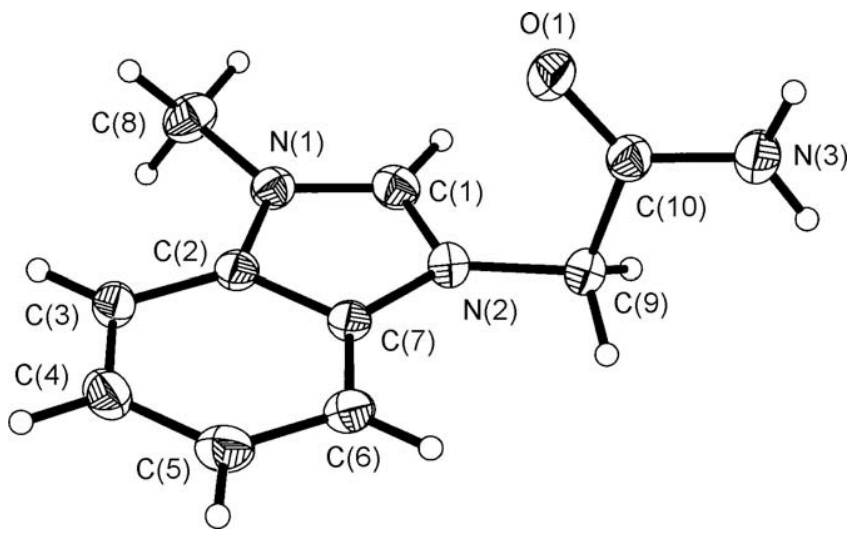

Fig. 2. Molecular structure of the cation in $\mathbf{2}$ showing $50 \%$ probability thermal ellipsoids. Selected bond lengths $(\AA)$ and angles $\left(^{\circ}\right)$ : $\mathrm{C}(1)-\mathrm{N}(1)$ : $1.320(3) ; \mathrm{C}(1)-\mathrm{N}(2)$ : 1.334(3); $\mathrm{C}(10)-\mathrm{O}(1)$ : $1.220(3) ; \mathrm{C}(10)-\mathrm{N}(3)$ : $1.319(3) ; \mathrm{N}(1)-\mathrm{C}(1)-\mathrm{N}(2): 110.8(2)$. 1683(vs), 1621(w), 1568(vw), 1479(w), 1442(w), 1421(vw) 1410(vw), 1391(m), 1257(w), 1203(w), 1162(vw), 1139(vw), 1085(vw), 1062(vw), 1020(vw), 970(vw), 890(vw), 863(vw), 813(w), 797(vw), 764(s), 687(m), 656(m), 626(w), and 453(vw) $\mathrm{cm}^{-1}$.

\subsection{6. [\{1-(Methylacetamido)-3-(methylimidazol-2- ylidene $\left.)\}_{2} \mathrm{Hg}\right]\left[\mathrm{HgBr}_{4}\right](\mathbf{6})$}

The preparation was similar to that of $\mathbf{5}$, except that $135.3 \mathrm{mg}$ ( $0.5 \mathrm{mmol})$ of 1-acetamido-3-methylbenzimidazolium bromide, $81.0 \mathrm{mg}(0.25 \mathrm{mmol})$ of mercury acetate and $43.0 \mathrm{mg}(0.25 \mathrm{mmol})$ of sodium acetate were used. A white solid was obtained (120.8 mg, 44\% yield). Anal. Calc. for $\mathrm{C}_{20} \mathrm{H}_{22} \mathrm{Br}_{4} \mathrm{Hg}_{2} \mathrm{~N}_{6} \mathrm{O}_{2}$ : C, 21.86; $\mathrm{H}, 2.02$; N, 7.65. Found: C, 21.67; H, 2.09; N, 7.71\%. ${ }^{1} \mathrm{H}$ NMR (DMSO-d $\left.)_{6}\right): \delta 7.96\left(\mathrm{~m}, 2 \mathrm{H}, \mathrm{C}_{6} \mathrm{H}_{4}, \mathrm{NH}_{2}\right), 7.82\left(\mathrm{~m}, 1 \mathrm{H}, \mathrm{C}_{6} \mathrm{H}_{4}\right), 7.67$ $\left(\mathrm{m}, 3 \mathrm{H}, \mathrm{C}_{6} \mathrm{H}_{4}, \mathrm{NH}_{2}\right), 5.54\left(\mathrm{~s}, 2 \mathrm{H}, \mathrm{CH}_{2}\right)$, and $4.28 \mathrm{ppm}\left(\mathrm{s}, 3 \mathrm{H}, \mathrm{CH}_{3}\right)$. ${ }^{13} \mathrm{C}$ NMR (DMSO- $\left.d_{6}\right): \delta 184.64(\mathrm{NCN}), 168.24(\mathrm{CO}), 133.70$, 126.25, 126.07, 113.42, $112.97\left(\mathrm{C}_{6} \mathrm{H}_{4}\right), 50.08\left(\mathrm{CH}_{2}\right)$ and $35.83 \mathrm{ppm}$ $\left(\mathrm{CH}_{3}\right)$. IR (KBr): 3348(w), 3328(w), 3304(w), 3249(vw), 3165(m), 3046(vw), 2916(vw), 2360(vw), 2337(vw), 1675(vs), 1609(w), 1568(vw), 1487(vw), 1461(s), 1418(w), 1403(m), 1362(w), 1351(vw), 1327(w), 1277(vw), 1261(vw), 1215(w), 1181(vw), 1139(vw), 1112(vw), 1028(vw), 974(vw), 939(vw), 886(vw), 836(vw), 794(w), 756(vw), 663(s), 652(w), 626(w), 614(w), and $576(\mathrm{w}) \mathrm{cm}^{-1}$.

\section{Results and discussion}

$N$-methylimidazole and $N$-methylbenzimidazole were alkylated with 2-bromoacetamide to afford 1-methylacetamido-3-methylimidazolium bromide (1) and 1-methylacetamido-3-methylbenzimidazolium bromide (2) (Scheme 1), respectively, in good yields. Analogous alkylation procedures have been used by Burgess and co-workers [34] and Ghosh and co-workers [35-37] in the prepa-

Table 2

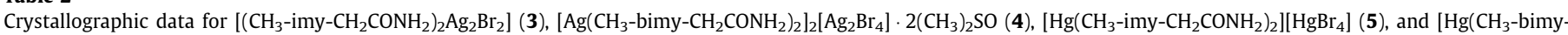
$\left.\left.\mathrm{CH}_{2} \mathrm{CONH}_{2}\right)_{2}\right]\left[\mathrm{HgBr}_{4}\right] \cdot\left(\mathrm{CH}_{3}\right)_{2} \mathrm{SO}(\mathbf{6})$

\begin{tabular}{|c|c|c|c|c|}
\hline Empirical formula & $\mathrm{C}_{12} \mathrm{H}_{18} \mathrm{Ag}_{2} \mathrm{Br}_{2} \mathrm{~N}_{6} \mathrm{O}_{2}$ & $\mathrm{C}_{44} \mathrm{H}_{56} \mathrm{Ag}_{4} \mathrm{Br}_{4} \mathrm{~N}_{12} \mathrm{O}_{6} \mathrm{~S}_{2}$ & $\mathrm{C}_{12} \mathrm{H}_{18} \mathrm{Br}_{4} \mathrm{Hg}_{2} \mathrm{~N}_{6} \mathrm{O}_{2}$ & $\mathrm{C}_{22} \mathrm{H}_{28} \mathrm{Br}_{4} \mathrm{Hg}_{2} \mathrm{~N}_{6} \mathrm{O}_{3} \mathrm{~S}$ \\
\hline Formula weight & 653.88 & 1664.25 & 999.15 & 1177.38 \\
\hline$T(\mathrm{~K})$ & $150(1)$ & $150(1)$ & $298(2)$ & $150(2)$ \\
\hline Crystal system & monoclinic & triclinic & monoclinic & triclinic \\
\hline Space group & $P 2(1) / c$ & $P \overline{1}$ & $P 2(1) / n$ & $P \overline{1}$ \\
\hline$a(\AA)$ & $4.3489(1)$ & $12.7840(5)$ & $8.1852(4)$ & $9.0753(4)$ \\
\hline$b(\AA)$ & $17.3223(5)$ & $15.0755(6)$ & $18.4391(8)$ & $10.6715(5)$ \\
\hline$c(\AA)$ & $11.7995(3)$ & $15.9313(6)$ & $15.2104(7)$ & $17.5450(8)$ \\
\hline$\alpha\left(^{\circ}\right)$ & & $108.820(1)$ & & $84.435(1)$ \\
\hline$\beta\left(^{\circ}\right)$ & $91.0179(14)$ & $93.416(1)$ & $93.8540(10)$ & $88.251(1)$ \\
\hline$\gamma\left({ }^{\circ}\right)$ & & $106.007(1)$ & & $65.792(1)$ \\
\hline$V\left(\AA^{3}\right)$ & $888.75(4)$ & $2756.05(19)$ & $2290.48(18)$ & $1542.38(12)$ \\
\hline$Z$ & 2 & 2 & 2 & 2 \\
\hline$\rho_{\text {calc }}\left(\mathrm{g} / \mathrm{cm}^{3}\right)$ & 2.443 & 2.005 & 2.897 & 2.535 \\
\hline Crystal size $\left(\mathrm{mm}^{3}\right)$ & $0.40 \times 0.06 \times 0.02$ & $0.15 \times 0.10 \times 0.05$ & $0.1 \times 0.05 \times 0.03$ & $0.20 \times 0.15 \times 0.10$ \\
\hline Radiation $(\lambda, \AA)$ & Mo K $\alpha(0.71073)$ & Mo K $\alpha(0.71073)$ & Mo K $\alpha(0.71073)$ & Mo K $\alpha(0.71073)$ \\
\hline$\theta$ limits $\left({ }^{\circ}\right)$ & $2.09-27.50$ & $1.37-25.00$ & $1.74-25.05$ & $1.17-27.50$ \\
\hline \multirow[t]{3}{*}{ Index ranges } & $-5 \leqslant h \leqslant 5$ & $-15 \leqslant h \leqslant 15$ & $-9 \leqslant h \leqslant 9$ & $-11 \leqslant h \leqslant 11$ \\
\hline & $-21 \leqslant k \leqslant 22$ & $-17 \leqslant k \leqslant 17$ & $-21 \leqslant k \leqslant 21$ & $-13 \leqslant k \leqslant 13$ \\
\hline & $-15 \leqslant l \leqslant 15$ & $-18 \leqslant l \leqslant 18$ & $-18 \leqslant l \leqslant 15$ & $-22 \leqslant l \leqslant 22$ \\
\hline Reflections collected & 8550 & 30345 & 12206 & 24848 \\
\hline Unique reflections & 2046 & 9698 & 4019 & 13978 \\
\hline$F(000)$ & 624 & 1624 & 1792 & 1084 \\
\hline Completeness to $\theta(\%)$ & 99.9 & 100.0 & 99.1 & 99.9 \\
\hline$\mu\left(\mathrm{mm}^{-1}\right)$ & 6.718 & 4.432 & 20.386 & 15.226 \\
\hline Max./min. transmission & $0.882,0.709$ & $0.8088,0.5561$ & $1,0.615917$ & $0.3113,0.1507$ \\
\hline Data/restraints/parameters & $2046 / 0 / 110$ & $9698 / 0 / 650$ & $4019 / 0 / 238$ & $13978 / 3 / 664$ \\
\hline$R_{1}^{\mathrm{a}}[I>2.0 \sigma(I)]$ & 0.0307 & 0.0697 & 0.0333 & 0.0598 \\
\hline$w R_{2}^{\mathrm{b}}$ (all data) & 0.0799 & 0.1491 & 0.0656 & 0.1393 \\
\hline$R_{\text {int }}$ & 0.0427 & 0.0526 & 0.0286 & 0.0501 \\
\hline Goodness-of-fit on $F^{2}$ & 1.012 & 1.309 & 1.042 & 1.016 \\
\hline
\end{tabular}

${ }^{\mathrm{a}} R_{1}=\sum\left\|F_{\mathrm{o}}\right\|-\left|F_{\mathrm{c}}\left\|/ \sum\right\| F_{\mathrm{o}}\right|$.

b $w R_{2}=\left\{\sum w\left(F_{\mathrm{o}}^{2}-F_{\mathrm{c}}^{2}\right)^{2} / \sum w\left(F_{\mathrm{o}}^{2}\right)^{2}\right\}^{1 / 2}$. 
ration of their amido-functionalized $\mathrm{N}$-heterocyclic carbene ligand precursors. In the ${ }^{1} \mathrm{H}$ NMR spectra in deuterated DMSO, the diagnostic acidic $2 \mathrm{H}$-imidazolium protons appear at $9.08 \mathrm{ppm}$ for $\mathbf{1}$ and $9.79 \mathrm{ppm}$ for $\mathbf{2}$. The amide protons of $\mathbf{1}$ (7.51 and $7.86 \mathrm{ppm}$ ) and $\mathbf{2}$ (7.68 and $8.03 \mathrm{ppm}$ ) are not equivalent due to a partial double bond character of the $\mathrm{C}(\mathrm{O})-\mathrm{NH}_{2}$ bond. These chemical shifts are slightly downfield compared with those of 2-bromoacetamide (7.25 and $7.62 \mathrm{ppm}$ ), thereby suggesting the presence of a $\mathrm{Br} \cdots \mathrm{H}-$ $\mathrm{N}$ type hydrogen bonding in solution between the $\mathrm{Br}^{-}$anion and the amide protons of the cation. Similar hydrogen bonding interactions have been found, for examples, in compound [1-(R)-3- $\{\mathrm{N}-(t-$ butylacetamido)imidazol-2-ylidene $\}]_{2} \mathrm{AgCl}(\mathrm{R}=t$-Bu, $i$-Pr $)[27,28]$ and compound [N-(2,6-diisopropylphenyl)-3-[bis(2-pyridylmethyl)amino]propanamide] $\mathrm{CuCl}$ [38]. The ${ }^{1} \mathrm{H}$ NMR spectra of $\mathbf{1}$ and 2 taken at $60{ }^{\circ} \mathrm{C}$ both display their amide signals merged into singlets at 7.37 and $7.56 \mathrm{ppm}$, respectively.

Crystals of $\mathbf{1}$ and $\mathbf{2}$ suitable for single crystal X-ray diffraction analyses were grown from methanol solution at $0^{\circ} \mathrm{C}$. The solid state molecular structures of $\mathbf{1}$ and $\mathbf{2}$ (Table 1, Figs. 1 and 2) provide evidence for the partial double bond character of the $\mathrm{C}(\mathrm{O})$ $\mathrm{NH}_{2}$ bond and the hydrogen bonding between the bromide anion and the amide protons. The $\mathrm{C}(\mathrm{O})-\mathrm{NH}_{2}$ bond distances are 1.326(3) $\AA$ in $\mathbf{1}$ and 1.319 (3) $\AA$ in 2, which are shorter than the sum of the individual single bond covalent radii of $\mathrm{C}(0.772 \AA)$ and $\mathrm{N}(0.70 \AA)$ [39]. The closest $\mathrm{Br} \cdots \mathrm{N}$ distances, $3.361 \AA$ in 1 and $3.372 \AA$ in 2 , are within the value of the sum of the van der Waals radii of $\mathrm{Br}$ and $\mathrm{N}(3.35-3.55 \AA$ ) [40].

Upon reaction with $\mathrm{Ag}_{2} \mathrm{O}, \mathbf{1}$ and 2 produced the silver-carbene complexes [ $\left.\left(\mathrm{CH}_{3} \text {-imy- } \mathrm{CH}_{2} \mathrm{CONH}_{2}\right)_{2} \mathrm{Ag}_{2} \mathrm{Br}_{2}\right]$ (3) and [ $\mathrm{Ag}\left(\mathrm{CH}_{3}\right.$-bimy$\left.\left.\mathrm{CH}_{2} \mathrm{CONH}_{2}\right)_{2}\right]_{4}\left[\mathrm{Ag}_{4} \mathrm{Br}_{8}\right]$ (4) (Scheme 1), respectively. With mercury acetate, $\mathbf{1}$ and $\mathbf{2}$ afforded the mercury-carbene complexes $\left[\mathrm{Hg}\left(\mathrm{CH}_{3} \text {-imy- } \mathrm{CH}_{2} \mathrm{CONH}_{2}\right)_{2}\right]\left[\mathrm{HgBr}_{4}\right]$ (5) and $\left[\mathrm{Hg}\left(\mathrm{CH}_{3}\right.\right.$-bimy$\left.\left.\mathrm{CH}_{2} \mathrm{CONH}_{2}\right)_{2}\right]\left[\mathrm{HgBr}_{4}\right](6)$ (Scheme 1), respectively. At room temperature these $\mathrm{N}$-heterocyclic carbene metal complexes are neither air nor light-sensitive.

Formation of the metal carbene complexes is corroborated by the absence of the $2 \mathrm{H}$-imidazolium proton signals in their ${ }^{1} \mathrm{H}$ NMR spectra. For each metal carbene complex the nonequvalent amide protons appear as a pair of singlets (7.31 and $7.63 \mathrm{ppm}$ (3); 7.44 and $7.76 \mathrm{ppm}$ (4); 7.46 and $7.84 \mathrm{ppm} \mathrm{(5);} 7.67$ and $7.96 \mathrm{ppm}(\mathbf{6})$ ). These chemical shifts are also slightly downfield from those of 2-bromoacetamide, which was attributed to the effect of the hydrogen bonding in solution. In the ${ }^{13} \mathrm{C}$ spectra of the above complexes the carbene signals appear as sharp singlets at about $40 \mathrm{ppm}$ downfield from that of the (benz)imidazolium salt. The ${ }^{107,109} \mathrm{Ag}-{ }^{13} \mathrm{C}$ coupling in 3 and $\mathbf{4}$ or the ${ }^{199} \mathrm{Hg}-{ }^{13} \mathrm{C}$ coupling in $\mathbf{5}$ and $\mathbf{6}$ is not observed, which could be attributed to the fluxional behavior of the labile metal-carbene bonds [23,41-44].

Crystals of 3-6 suitable for X-ray diffraction analyses were obtained through slow evaporation of their DMSO solutions at room temperature. The unit cell of $\mathbf{4}$ contains two DMSO solvent molecules and the unit cell of $\mathbf{6}$ contains one DMSO solvent molecule. The crystal data for 3-6 are provided in Table 2. The molecular structures of 3-6 are shown in Figs. 3-6, and the selected bond distances and angles are given in the figure captions. Due to the presence of inversion centers the asymmetric units for $\mathbf{3}$ and $\mathbf{5}$ are comprised of half of the molecule in both cases.

An important feature of the silver carbene complexes is their structural diversity in the solid state, which ranges from a simple monomer to different types of polymeric structures [45-48]. Com-
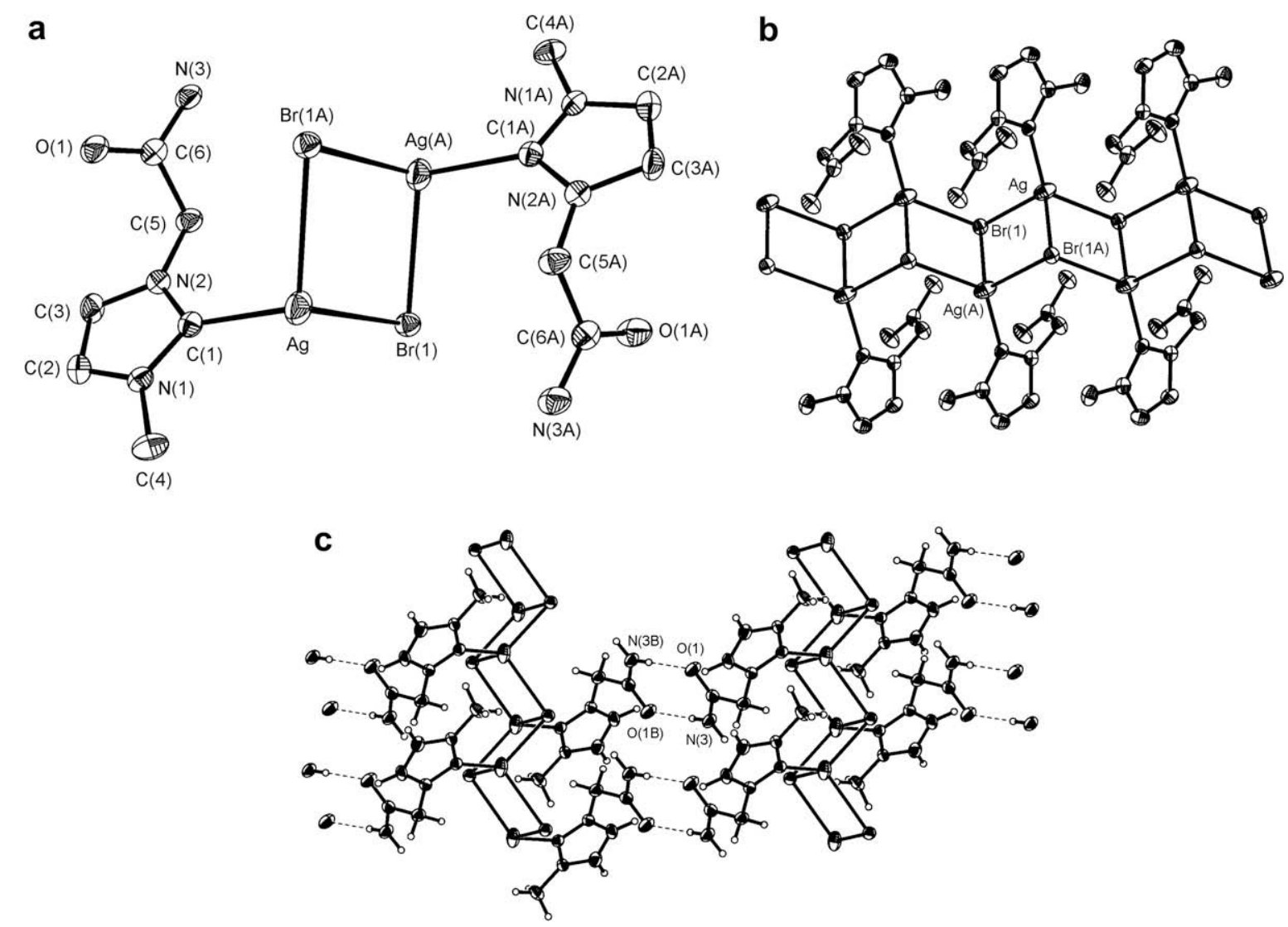

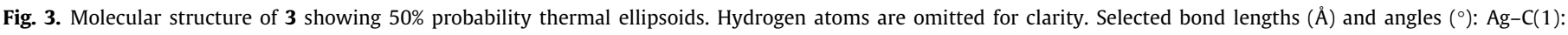

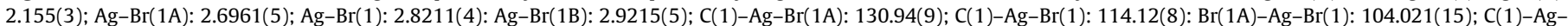

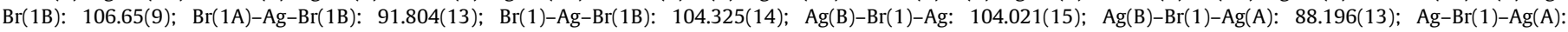
75.675(14); N(1)-C(1)-N(2): 104.4(3). 
plex 3 is a neutral species composed of $\left(\mathrm{CH}_{3}\right.$-imy- $\left.\mathrm{CH}_{2} \mathrm{CONH}_{2}\right) \mathrm{AgBr}$ repeating units. Two of such units are held together by two bridging bromine atoms to form a dimeric structure (Fig. 3a). The crystal packing revealed the $2 \mathrm{D}$ polymeric structure of 3 . A one-dimensional staircase polymer chain is formed through an extended $\mathrm{Ag}-\mathrm{Br}$ interaction of the $\mathrm{Ag}_{2} \mathrm{Br}_{2}$ rhombic structure (Fig. 3b). Each $\mathrm{Ag}$ atom coordinated to a carbene carbon and three $u_{3}$-bridging $\mathrm{Br}$ ligands is in a tetrahedral environment. The $\mathrm{Ag}-\mathrm{C}_{\text {carb }}$ bond distance of 2.155(3) $\AA$ is longer than the sum of individual covalent radii of $\mathrm{Ag}$ and $\mathrm{C}(2.11 \AA$ ) [39], but slightly shorter than that found in [(allyl-imy-CH $\left.\left.\mathrm{CH}_{3}\right) \mathrm{Ag}\right]\left[\mathrm{AgI}_{2}\right]$ (2.161(9) $\AA$ ) [49,50]. The Ag-Br distances of 2.6961(5), 2.8211(4), and 2.9215(5) $\AA$ are comparable to other $\mathrm{Ag}-\mathrm{Br}$ bonds characteristic for tetrahedral coordination $[23,51,52]$. Within the $\mathrm{Ag}_{2} \mathrm{Br}_{2}$ rhombic structure, the $\mathrm{Br}(1)-\mathrm{Ag}-$ $\mathrm{Br}(1 \mathrm{~B})$ angle $\left(104.325(14)^{\circ}\right)$ is larger than the $\mathrm{Ag}-\mathrm{Br}(1)-\mathrm{Ag}(\mathrm{A})$ $\left(75.675(14)^{\circ}\right)$. The $\mathrm{Ag}-\mathrm{Ag}$ distance is $3.524 \AA$, which is slightly longer than the sum of the van der Waals radii for two silver atoms [40].

In addition to the extended $\mathrm{Ag}-\mathrm{Br}$ interaction, an intermolecular hydrogen bonding interaction between the amide $\mathrm{NH}_{2}$ protons and the adjacent amide oxygen atom was also found. As shown in Fig. 3c, each amido group of the repeating unit of the one-dimensional polymer is hydrogen bonded to the adjacent amido group of the repeating unit forming a 2D supramolecular architecture. The $\mathrm{N} \cdots \mathrm{O}$ distance of $2.936 \AA$ is smaller than the sum of the van der Waals radii of $\mathrm{N}$ and $\mathrm{O}$ atoms (3.05 $\AA$ ) [40]. Indeed, the same type of the dimer structure is also found for the amido-functionalized metal carbene complexes 4-6.

The molecular structure of complex 4 is shown in Fig. 4. Complex 4 being ionic, the unit cell consists of two $\left[\mathrm{Ag}\left(\mathrm{CH}_{3}-\mathrm{Bim}\right.\right.$ $\left.\left.\mathrm{CH}_{2} \mathrm{CONH}_{2}\right)_{2}\right]^{+}$cations (Fig. 4a) and one half of the oligomeric $\left[\mathrm{Ag}_{4} \mathrm{Br}_{8}\right]^{4-}$ anion (Fig. 4b). The cations $\mathrm{C}-\mathrm{Ag}-\mathrm{C}$ angles are 170.6(3) and $169.6(3)^{\circ}$, which is consistent with other linear $\left[\mathrm{Ag}(\text { carbene })_{2}\right]^{+}$complexes $[49,50]$. The $\mathrm{Ag}-\mathrm{C}$ distances are 2.096(9), 2.097(8), 2.103(8) and 2.113(8) Å. Although these bond distances are shorter than those found in 3 , they fall in the range of $\mathrm{Ag}-\mathrm{C}$ bond distances (2.074(5)-2.131(5) $\AA$ ) generally found in other Ag-NHC complexes [15-19,23,35,53]. The crystal packing reveals the 1D polymeric structure of the cations through the hydrogen bonding between the amido groups of the adjacent cations. The N … distances are 2.912 and $2.956 \AA$ A . Hydrogen bonding was also found between the amido group and the DMSO solvent molecule. The closest distances between the amido nitrogen and the oxygen atom of $\left(\mathrm{CH}_{3}\right)_{2} \mathrm{SO}$ are 2.837 and $2.873 \AA$.

The unique oligomeric $\left[\mathrm{Ag}_{4} \mathrm{Br}_{8}\right]^{4-}$ anion is formed by four $\mathrm{Ag}$ atoms and eight bromine atoms. The Ag atoms are either in the distorted trigonal or tetrahedral environments, and three four-membered rings can be observed. Atoms $\operatorname{Ag}(3), \operatorname{Br}(1), \operatorname{Ag}(3 \mathrm{~A})$, and $\operatorname{Br}(1 \mathrm{~A})$ form an almost perfect square with $90.97(3)^{\circ}$ and $89.03(3)^{\circ}$ angles. The $\mathrm{Ag}-\mathrm{Br}$ distance for a terminal bromide is 2.5395(12) $\AA$. The Ag-Br distances for the bridging bromides are longer falling in the range of 2.6454(13)-2.7941(12) $\AA$. The Ag ...Ag distances are 3.504 and $3.828 \AA$ suggesting no $\mathrm{Ag}-\mathrm{Ag}$ interaction within the anion. To our knowledge, $\left[\mathrm{K}(\text { crypt-2,2,2) }]_{4}\left[\mathrm{Ag}_{4} \mathrm{Br}_{8}\right]\right.$ is the only example of a compound containing oligomeric $\left[\mathrm{Ag}_{4} \mathrm{Br}_{8}\right]^{4-}$ anion that has been reported in literature [54]. However, the bond distances and angles of $\left[\mathrm{Ag}_{4} \mathrm{Br}_{8}\right]^{4-}$ in $[\mathrm{K}(\mathrm{crypt}-2,2,2)]_{4}\left[\mathrm{Ag}_{4} \mathrm{Br}_{8}\right]$ are different from those found in 4 . In [K(crypt-2,2,2) $]_{4}\left[\mathrm{Ag}_{4} \mathrm{Br}_{8}\right]$, the terminal $\mathrm{Ag}-\mathrm{Br}$ distances are shorter $(2.518(2) \AA)$ and the bridging $\mathrm{Ag}-\mathrm{Br}$ distances are falling in a wider range (2.631(2)-2.799(2) $\mathrm{A}$ ), and the $\mathrm{Ag} \ldots \mathrm{Ag}$ distances are 3.562(1) and 3.595(2) $\AA$. The angles of the "square" formed by the $\operatorname{Ag}(3), \operatorname{Br}(1), \operatorname{Ag}(3 \mathrm{~A})$ and $\operatorname{Br}(1 \mathrm{~A})$ atoms in $\left[\mathrm{K}(\text { crypt-2,2,2) }]_{4}\left[\mathrm{Ag}_{4} \mathrm{Br}_{8}\right]\right.$ are $96.87(4)^{\circ}$ and $83.13(4)^{\circ}$ [54]. Different cations in these two compounds resulting in different crystal packing forces could account for such a difference in the bond distances and angles of the anions.
For complex 5, an ionic compound, two $\left[\mathrm{Hg}\left(\mathrm{CH}_{3}\right.\right.$-imy$\left.\left.\mathrm{CH}_{2} \mathrm{CONH}_{2}\right)_{2}\right]^{2+}$ cations and two $\left[\mathrm{HgBr}_{4}\right]^{2-}$ anions with slightly different bond distances and angles are found in the unit cell. The C$\mathrm{Hg}-\mathrm{C}$ angle values found for each cation $\left(179.999(2)^{\circ}\right.$ and $\left.179.999(3)^{\circ}\right)$ are consistent with those found for 1,3-diphenylimidzol-2-ylidene mercury perchlorate $\left(180^{\circ}\right)[2,4]$. The $\mathrm{Hg}-$ C bond distances are 2.078(9) and 2.051(9) Å. The previously reported mercury carbene $\mathrm{Hg}-\mathrm{C}$ bond distances fall into the range of 1.97(2)-2.22(3) $\AA[2,4,53,55,56]$. Unlike the silver complexes 3 and $\mathbf{4}$, the mercury complex is characterized by an interaction between an amide oxygen and the mercury atom. The $\mathrm{Hg} \ldots \mathrm{O}$ distances of 2.794 and $2.802 \AA$ are shorter than the sum of the van der Waals radii of $\mathrm{O}$ and $\mathrm{Hg}$ atoms (3.0 $\AA$ ) [40], suggesting a weak interaction of the amide group with the $\mathrm{Hg}$ atom, which may be resulted from the higher oxidation state of the mercury ion compared with that of the $\mathrm{Ag}(\mathrm{I})$ in the silver carbene complexes. The $\mathrm{Hg}-\mathrm{Br}$ distances of the anions are falling in the range of 2.5796(11)-2.6351(11) Å. Crystal packing revealed a 2D polymeric structure of complex $\mathbf{5}$. One dimension of the polymer chain is forged by the $\mathrm{Hg} \cdots \mathrm{Br}$ interaction between the anion and the cation. The $\mathrm{Hg}(1) \cdots \operatorname{Br}(2)$ and $\mathrm{Hg}(2) \cdots \mathrm{Br}(1)$ distances are 3.227 and $3.386 \AA$, respectively. These distances are within the sum of the van der Waals radii of $\mathrm{Br}$ and $\mathrm{Hg}$ atoms (3.3-3.5 $\AA$ ) [40]. The hydrogen bonds between the amido groups of the adjacent cations constitute the other dimension of the polymer chain. The $\mathrm{N} \cdots \mathrm{O}$ distance for the adjacent amido groups is $2.901 \AA$.

Previously we have prepared the mercury amido-functionalized carbene complexes [ $\left.\mathrm{Hg}\left(2 \text {-pyrazinyl-imy- } \mathrm{CH}_{2} \mathrm{CONH}_{2}\right)_{2}\right] \mathrm{X}\left(\mathrm{X}=\mathrm{PF}_{6}\right.$, $\left.\mathrm{BF}_{4}\right)$ and $\left[\mathrm{Hg}\left(2 \text {-pyrimidyl-imy- } \mathrm{CH}_{2} \mathrm{CONH}_{2}\right)_{2}\right] \mathrm{X}\left(\mathrm{X}=\mathrm{BF}_{4}\right)$ [26]. The interaction between mercury and nitrogen atoms of the pyrazinyl
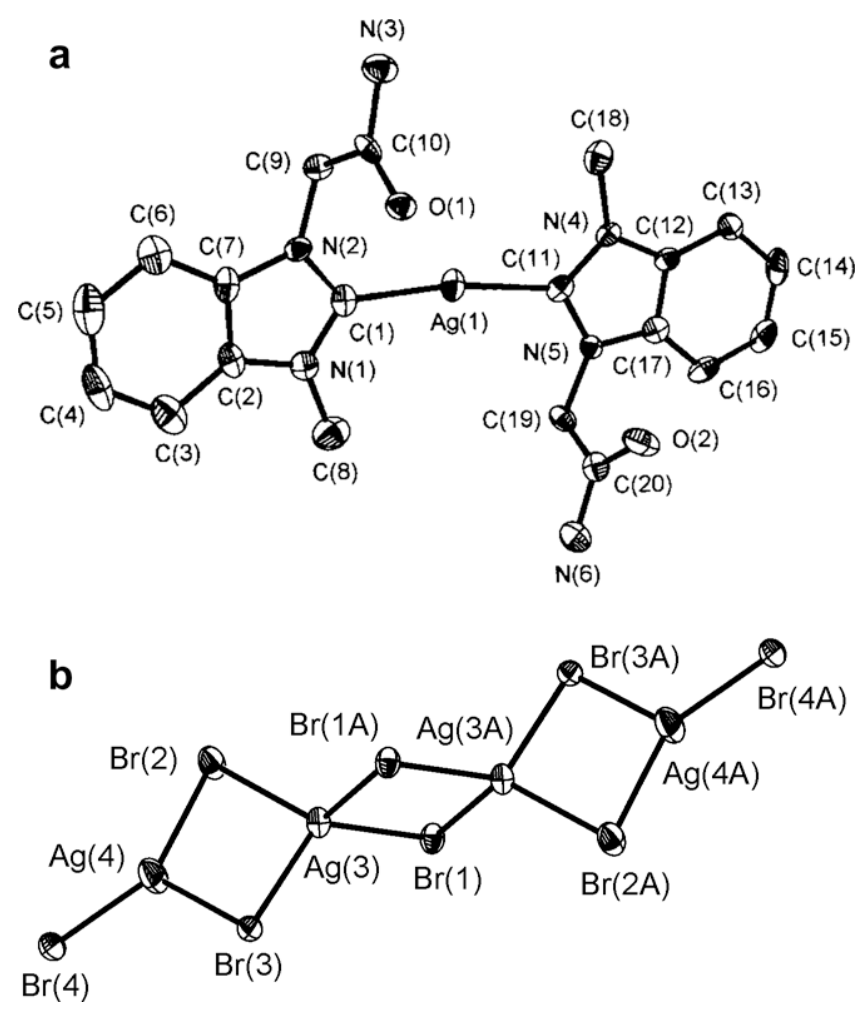

Fig. 4. Molecular structure of 4 showing 50\% probability thermal ellipsoids. Hydrogen atoms and solvent molecules are omitted for clarity. Selected bond lengths $(\AA)$ and angles $\left(^{\circ}\right): A g(1)-C(1): 2.097(8) ; A g(1)-C(11): 2.096(9) ; A g(2)-$ $\mathrm{C}(21): 2.103(8) ; \mathrm{Ag}(2)-\mathrm{C}(31): 2.113(8) ; \mathrm{C}(11)-\mathrm{Ag}(1)-\mathrm{C}(1): 170.6(3) ; \mathrm{C}(21)-\mathrm{Ag}(2)-$ $\mathrm{C}(31): 169.6(3) ; \mathrm{N}(1)-\mathrm{C}(1)-\mathrm{N}(2): 106.3(7) ; \mathrm{N}(4)-\mathrm{C}(11)-\mathrm{N}(5): 105.7(7) ; \mathrm{N}(7)-$ $\mathrm{C}(21)-\mathrm{N}(8): \quad 105.3(7) ; \quad \mathrm{N}(10)-\mathrm{C}(31)-\mathrm{N}(11): \quad 105.9(7) ; \quad \operatorname{Br}(1)-\mathrm{Ag}(3)-\operatorname{Br}(1 \mathrm{~A})$ : 90.97(3); $\mathrm{Ag}(3)-\operatorname{Br}(1)-\mathrm{Ag}(3 \mathrm{~A}): 89.03(3)^{\circ}$. 
(pyrimidyl) substitute produced a skewed $\mathrm{Hg}$-carbene core conformation that forced the two amido groups to be on the same side and formed a U-shaped building block. In the crystal packing, the intermolecular hydrogen bonding interaction between the adjacent amido groups connects the U-shaped building blocks leading to a rectangular architecture. In the alkyl- substituted analog of complex 5 lacking the $\mathrm{Hg}-\mathrm{N}$ interaction found in complexes $\left[\mathrm{Hg}\left(2 \text {-pyrazinyl-imy- } \mathrm{CH}_{2} \mathrm{CONH}_{2}\right)_{2}\right] \mathrm{X} \quad\left(\mathrm{X}=\mathrm{PF}_{6}, \mathrm{BF}_{4}\right)$ and $[\mathrm{Hg}(2-$ pyrimidyl-imy- $\left.\left.\mathrm{CH}_{2} \mathrm{CONH}_{2}\right)_{2}\right] \mathrm{X}\left(\mathrm{X}=\mathrm{BF}_{4}\right)$, a trans-anti conformation precluded the $\mathrm{U}$-shaped conformations of the amido groups and the resulting rectangular architecture. It is noteworthy that without the $\mathrm{Hg}-\mathrm{N}$ interaction, a weak interaction between the amido oxygen and the mercury atom was observed.

Complex 6 is also an ionic compound, containing two $\left[\mathrm{Hg}\left(\mathrm{CH}_{3}-\right.\right.$ bimy- $\left.\left.\mathrm{CH}_{2} \mathrm{CONH}_{2}\right)_{2}\right]^{2+}$ cations and two $\left[\mathrm{HgBr}_{4}\right]^{2-}$ anions in the unit cell. The $\mathrm{C}-\mathrm{Hg}-\mathrm{C}$ angles of the two cations are $174.8(6)^{\circ}$ and $176.5(6)^{\circ}$. The $\mathrm{Hg}-\mathrm{C}$ bond distances are 2.070(15), 2.089(15), 2.064(16) and 2.121(15) $\AA$. The Hg-Br bond distances of the anions are falling in the range of 2.5501(19)-2.6753(18) $\AA$. The weak interactions and the 2D polymeric structure observed for complex 5 are also found in complex $\mathbf{6}$. The $\mathrm{Hg}$... O distances between mercury and oxygen atoms of the amido group are 2.802 and $2.827 \AA$ for $\mathrm{Hg}(1)$ and 2.780 and $3.040 \AA$ for $\mathrm{Hg}(2)$. The $\mathrm{Hg}$... Br distances between the cation and the anion are in the range of 3.193-3.483 $\AA$. The $\mathrm{N}$... O distances for the adjacent amido group of the cations are determined to be $2.880,2.960,2.847$ and 2.922 Å. Hydrogen bonds between the amido group and the solvent molecule are also found in 6. The closest $\left(\mathrm{CH}_{3}\right)_{2} \mathrm{SO} \cdots \mathrm{N}$ distances between the amido nitrogen and oxygen of DMSO are 2.894 and $3.352 \AA$. It is noteworthy that many carbene complexes containing benzimidazole-2-ylidene display a $\pi-\pi$ stacking interactions between the aromatic rings of the adjacent molecules [19,57]. This type of interaction was not found in complexes $\mathbf{4}$ and $\mathbf{6}$, possibly due to the stronger hydrogen bonding interaction between the amido groups of the adjacent molecules.

In summary, the amido-functionalized carbene ligand precursors and corresponding silver and mercury carbene complexes have been prepared and characterized. While $\mathbf{3}$ is a neutral compound, 4-6 are ionic. In addition to the metal-carbene interaction, a weak interaction between the amide oxygen and the mercury atom were also found in complexes $\mathbf{5}$ and $\mathbf{6}$, possibly due to the higher oxidation state of mercury. A hydrogen bonding interaction of the amido groups of the adjacent cations is responsible for the one-dimensional polymeric structure found in $\mathbf{4}$. In addition to
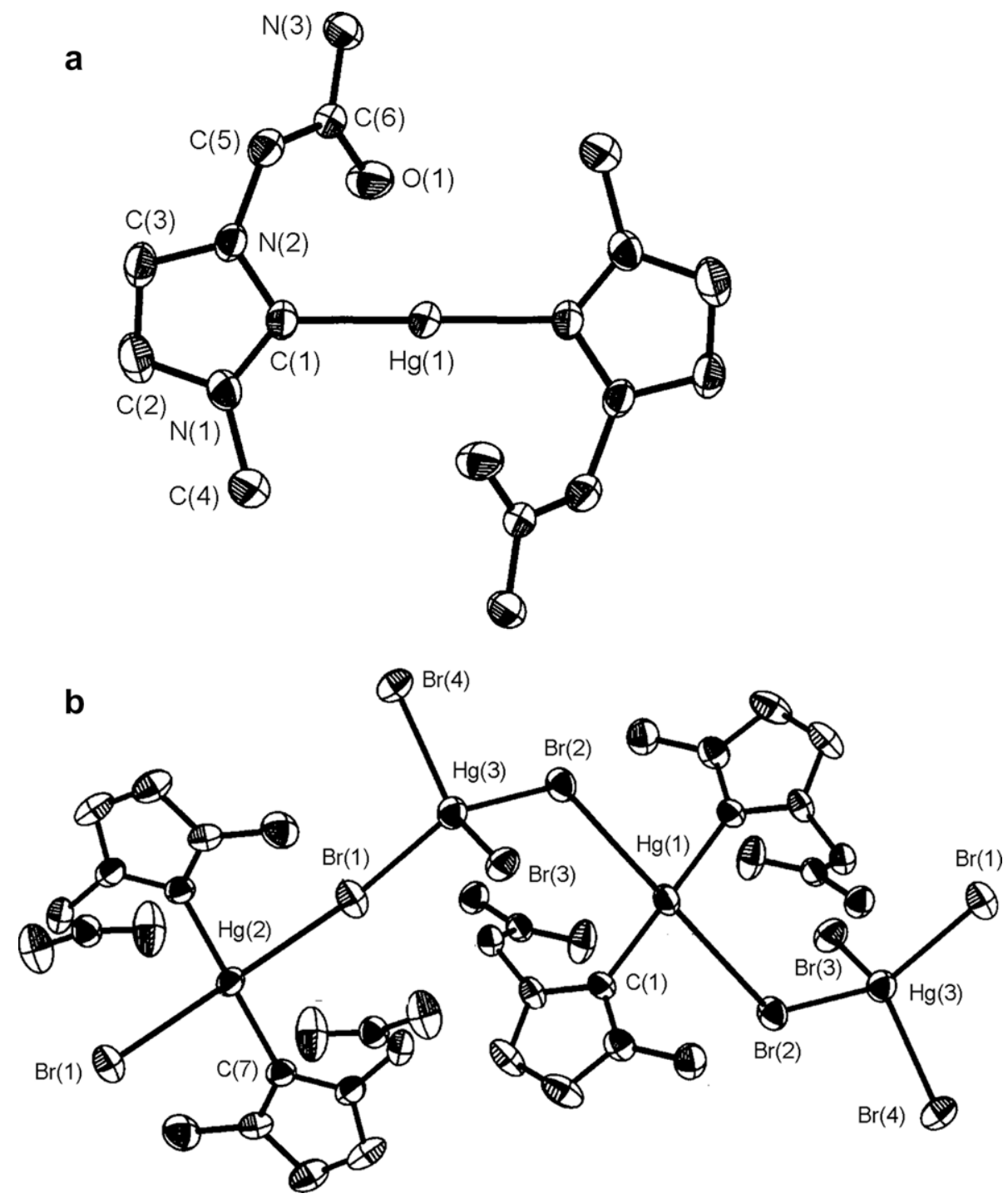

Fig. 5. Molecular structure of 5 showing $50 \%$ probability thermal ellipsoids. Hydrogen atoms are omitted for clarity. Selected bond lengths ( $(\AA)$ and angles $\left({ }^{\circ}\right)$ : Hg(1)-C(1): 2.078(9); $\mathrm{Hg}(2)-\mathrm{C}(7): 2.051(9) ; \mathrm{C}(1)-\mathrm{Hg}(1)-\mathrm{C}(1 \mathrm{~A}): 179.999(2) ; \mathrm{C}(7)-\mathrm{Hg}(2)-\mathrm{C}(7 \mathrm{~B}): 179.999(3) ; \mathrm{N}(1)-\mathrm{C}(1)-\mathrm{N}(2): 106.5(8) ; \mathrm{N}(4)-\mathrm{C}(7)-\mathrm{N}(5) ; 106.3(8)$. 

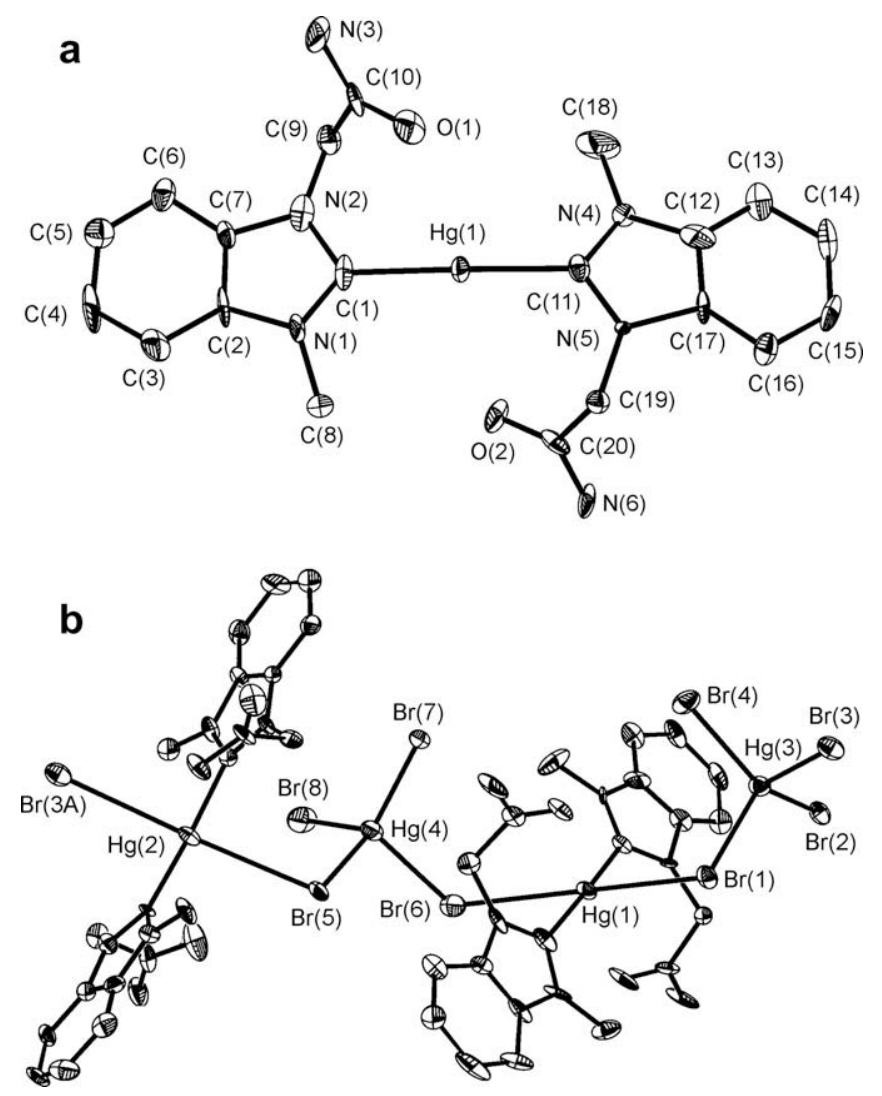

Fig. 6. Molecular structure of $\mathbf{6}$ showing $50 \%$ probability thermal ellipsoids. Hydrogen atoms and solvent molecules are omitted for clarity. Selected bond lengths $(\AA)$ and angles $\left(^{\circ}\right): \mathrm{Hg}(1)-\mathrm{C}(1): 2.070(15) ; \mathrm{Hg}(1)-\mathrm{C}(11): 2.089(15) ; \mathrm{Hg}(2)-$ $\mathrm{C}(21): 2.064(16) ; \mathrm{Hg}(2)-\mathrm{C}(31): 2.121(15) ; \mathrm{C}(1)-\mathrm{Hg}(1)-\mathrm{C}(11): 174.8(6) ; \mathrm{N}(1)-\mathrm{C}(1)-$ $\mathrm{N}(2): 106.7(14) ; \mathrm{N}(4)-\mathrm{C}(11)-\mathrm{N}(5): 108.1(13) ; \mathrm{C}(21)-\mathrm{Hg}(2)-\mathrm{C}(31): 176.5(6) ; \mathrm{N}(7)-$ $\mathrm{C}(21)-\mathrm{N}(8)$ : 105.6(13); N(10)-C(31)-N(11): 111.0(14).

the hydrogen bonding, an extended $\mathrm{Ag}-\mathrm{Br}$ interaction in $\mathbf{3}$ and the interaction between the cation and the anion in $\mathbf{5}$ and $\mathbf{6}$ constitute another dimension of the polymeric structure resulting in a twodimensional supramolecular architecture.

\section{Acknowledgment}

This work was financially supported by the National Science Council of the ROC through Grant NSC 96-2113-M-259-014.

\section{Appendix A. Supplementary material}

CCDC 698275, 698276, 698277, 698278, 698279 and 698280 contains the supplementary crystallographic data for this paper. These data can be obtained free of charge from The Cambridge Crystallographic Data Centre via www.ccdc.cam.ac.uk/data_request/cif. Supplementary data associated with this article can be found, in the online version, at doi:10.1016/j.ica.2009.03.014.

\section{References}

[1] K. Öfele, J. Organomet. Chem. 12 (1968) 42.

[2] H.-W. Wanzlick, H.-J. Schönherr, Angew. Chem. 80 (1968) 154.

[3] H.-W. Wanzlick, H.-J. Schönherr, Angew. Chem., Int. Ed. Engl. 7 (1968) 141.
[4] P. Luger, G. Ruban, Acta Crystallogr., Sect. B 27 (1971) 2276.

[5] A.J. Arduengo III, R.L. Harlow, M. Kline, J. Am. Chem. Soc. 113 (1991) 361

[6] F.E. Hahn, M.C. Jahnke, Angew. Chem., Int. Ed. Engl. 47 (2008) 3122.

[7] W.A. Herrmann, C. Köcher, Angew. Chem., Int. Ed. Engl. 41 (2002) 1290.

[8] O. Kaufhold, F.E. Hahn, Angew. Chem., Int. Ed. Engl. 47 (2008) 4057.

[9] A.A. Danopoulos, N. Tsoureas, S.A. Macgregor, C. Smith, Organometallics 26 (2007) 253.

[10] W.A. Hermann, L.J. Goossen, C. Köcher, G.R.J. Artus, Angew. Chem., Int. Ed. Engl. 35 (1996) 2805.

[11] W.A. Herrmann, G. Gerstberger, M. Spiegler, Organometallics 16 (1997) 2209.

[12] D. Enders, H. Gielen, G. Raabe, J. Runsink, J.H. Teles, Chem. Ber. 129 (1996) 1483.

[13] J.H. Teles, J.-P. Melder, K. Ebel, R. Schneider, E. Gehrer, W. Harder, S. Brode, D Enders, K. Breuer, G. Raabe, Helv. Chim. Acta 79 (1996) 61.

[14] Q.X. Liu, F.B. Xu, Q.S. Liu, H.B. Song, Z.Z. Zhang, Organometallics 23 (2004) 610

[15] K.J. Cavell, D.S. McGuinness, Coord. Chem. Rev. 248 (2004) 671.

[16] C.M. Crudden, D.P. Allen, Coord. Chem. Rev. 248 (2004) 2247.

[17] J. Ruiz, G. Garcia, M.E.G. Mosquera, B.F. Perandones, M.P. Conzalo, M. Vivanco, J. Am. Chem. Soc. 127 (1999) 8584.

[18] E. Despagnet-Ayoub, R.H. Grubbs, Organometallics 24 (2005) 338.

[19] Q.-X. Liu, X.-J. Zhao, X.-M. Wu, J.-H. Guo, X.-G. Wang, J. Organomet. Chem. 692 (2007) 5671.

[20] O. Guerret, S. Solé, H. Gornitzka, M. Teichert, G. Trinquier, G. Bertrand, J. Am. Chem. Soc. 119 (1997) 6668.

[21] C.K. Lee, J.C.C. Chen, K.M. Lee, C.W. Liu, I.J.B. Lin, Chem. Mater. 11 (1999) 1237.

[22] J.C.C. Chen, I.J.B. Lin, J. Chem. Soc., Dalton Trans. (2000) 839.

[23] K.M. Lee, H.M.J. Wang, I.J.B. Lin, J. Chem. Soc., Dalton Trans. (2002) 2852.

[24] F.E. Hahn, C. Radloff, T.P.A. Hepp, Chem. Eur. J. 14 (2008) 10900.

[25] F.E. Hahn, C. Radloff, T. Pape, A. Hepp, Organometallics 27 (2008) 6408

[26] K.M. Lee, J.C.C. Chen, C.J. Huang, I.J.B. Lin, CrystEngCommun. 9 (2007) 278.

[27] M.K. Samantaray, K. Pang, M.M. Shaikh, P. Ghosh, Inorg. Chem. 47 (2008) 4153.

[28] L. Ray, M.M. Shaikh, P. Ghosh, Inorg. Chem. 47 (2008) 230.

[29] Z. Otwinowsky, W. Minor, DEnzo-smn, Processing of X-ray diffraction data collected in oscillation mode, in: C.W. Carter Jr., R.M. Sweet (Eds.), Methods in Enzymology, Macromolecular Crystallography, Part A, vol. 276, Academic Press, New York, 1997, p. 307.

[30] R.H. Blessing, Acta Crystallogr., Sect. A 51 (1995) 33.

[31] R.H. Blessing, J. Appl. Crystallogr. 30 (1997) 421.

[32] G.M. Sheldrick, Acta Crystallogr., Sect. A 46 (1990) 467.

[33] G.M. Sheldrick, sHeLXL-97, University of Göttingen, Göttingen, Germany, 1997.

[34] M.C. Perry, X. Cui, K. Burgess, Tetrahedron: Asymmetry 13 (2002) 1969.

[35] M.K. Samantaray, V. Katiyar, D. Roy, K. Pang, H. Nanavati, R. Stephen, R.B. Sunoj, P. Ghosh, Eur. J. Inorg. Chem. (2006) 2975.

[36] M.K. Samantaray, V. Katiyar, K. Pang, H. Nanavati, P. Ghosh, J. Organomet Chem. 692 (2007) 1672.

[37] L. Ray, V. Katiyar, M.J. Raihan, H. Nanavati, M.M. Shaikh, P. Ghosh, Eur. J. Inorg. Chem. (2006) 3724

[38] T.E. Patten, C. Troeltzsch, M.M. Olmstead, Inorg. Chem. 44 (2005) 9197.

[39] L. Pauling, The Nature of the Chemical Bond, 3rd ed., Cornell University Press, Ithaca, NY, 1960. p. 224.

[40] A. Bondi, J. Phys. Chem. 68 (1964) 441.

[41] P.L. Arnold, A.C. Scarisbrick, A.J. Blake, C. Wilson, Chem. Commun. (2001) 2340.

[42] A.A.D. Tulloch, A.A. Danopoulos, S. Winston, S. Kleinhenz, G. Eastham, J. Chem. Soc., Dalton Trans. (2000) 4499.

[43] J.C. Garrison, R.S. Simons, J.M. Talley, C. Wesdemiotis, C.A. Tessier, W.J. Youngs, Organometallics 20 (2001) 1276.

[44] H.M.J. Wang, I.J.B. Lin, Organometallics 17 (1998) 972.

[45] I.J.B. Lin, C.S. Vasam, Coord. Chem. Rev. 251 (2007) 642.

[46] D. Pugh, A.A. Danopoulos, Coord. Chem. Rev. 251 (2007) 610.

[47] J.C. Garrison, W.J. Youngs, Chem. Rev. 105 (2005) 3978.

[48] P.L. Arnold, Heteroatom Chem. 13 (2002) 534.

[49] W. Chen, F. Liu, J. Organomet. Chem. Chem. 673 (2003) 5.

[50] F.A. Cotton, G. Wilkinson, C.A. Murillo, M. Bochmann, Advanced Inorganic Chemistry, 6th ed., Wiley, New York, 1999. p. 1085.

[51] R.J. Bowen, D. Camp, P.C. Hwaly, B.W. Skelton, A.H. White, Aust. J. Chem. 47 (1994) 693.

[52] L.M. Engelharde, S. Gotsis, P.C. Healy, J.D. Kildea, B.W. Skelton, A.H. White Aust. J. Chem. 42 (1989) 149.

[53] X.-J. Wan, F.-B. Xu, Q.-S. Li, H.-B. Song, Z.-Z. Zhang, Organometallics 24 (2005) 6066.

[54] G. Helgesson, S. Jagner, Inorg. Chem. 30 (1991) 2574.

[55] K.-M. Lee, J.C.C. Chen, I.J.B. Lin, J. Organomet. Chem. 617-618 (2001) 364

[56] A.J. Arduengo III, R.L. Harlow, W.J. Marshall, T.K. Prakasha, Heteroatom Chem. 7 (1996) 421.

[57] H. Sakurai, K. Sugitani, T. Moriuchi, T. Hirao, J. Organomet. Chem. 690 (2005) 1750. 